\title{
Higher Education, Information and Communication Technologies and Students with Disabilities: An Overview of the Current Situation
}

\author{
Catherine Fichten, Dorit Olenik-Shemesh, \\ Jennison Asuncion, Mary Jorgensen, and Chetz Colwell
}

\begin{abstract}
This chapter provides context for the issues discussed throughout the book to justify why the issue of students with disabilities using technology to support their studies in higher education continues to be both important and problematic. To do this, the chapter: (1) reviews current statistics regarding enrollment and success of students with disabilities in higher education; (2) examines the role and prevailing use of
\end{abstract}

\author{
C. Fichten $(\bowtie)$ \\ Dawson College and McGill University, Montreal, QC, Canada \\ e-mail: catherine.fichten@mcgill.ca \\ D. Olenik-Shemesh \\ The Open University, Ra'anana, Israel
}

J. Asuncion · M. Jorgensen

Adaptech Research Network, Montreal, QC, Canada

C. Colwell

The Open University, Milton Keynes, UK

(C) The Author(s) 2020 
information and communication technologies in higher education; (3) considers the potential of the next wave of new ICTs; (4) illuminates with examples the many good, bad and terrible practices related to ICTs experienced by students in higher education; and (5) discusses the implications for future research and practice.

Keywords ICT $\bullet$ Disability $\bullet$ Higher education $\bullet$ Trends $\bullet$ Predictions

\section{Statistics Regarding the Success of Students with Disabilities in Higher Education}

Over 11\% of students enrolled in two-year and four-year colleges in Canada and the United States have a disability (Fichten et al., 2018; Ministry of Training Colleges and Universities (Ontario), 2012; Snyder, de Brey, \& Dillow, 2016); however, the 2016 American Freshman Survey (Eagan et al., 2017), based on 137,456 full-time students who entered 184 American 4-year colleges and universities, found that $21.9 \%$ selfreported a disability. Similar percentages have been reported in other countries. For example, a recent investigation noted that $12 \%$ of undergraduates had a disability in the United Kingdom (Advance HE, 2018). These students encounter a variety of barriers in pursuing higher education ( $\mathrm{HE})$, including problems with support services, faculty attitudes, as well as technological problems.

Given their large numbers, understanding facilitators and barriers to the academic success of students with disabilities is vital. A variety of articles show that HE students with disabilities graduate at the same rate as students without disabilities, however, they take additional time to do so (Arim, 2017; Jorgensen et al., 2005; Knight, Wessel, \& Markle, 2018). Other investigations, however, show that students with disabilities are more likely to drop out than their nondisabled peers (DaDeppo, 2009; Newman, Wagner, Cameto, \& Knokey, 2009; Rosenbaum, 2018; Wessel, Jones, Markle, \& Westfall, 2009) and less likely to graduate (Advance HE, 2018). While some studies reported that the nature of students' disabilities was a factor (e.g., S. Jorgensen et al., 2003), other studies report no differences (e.g., Herbert et al., 2014). As Kimball, Wells, Ostiguy, Manly, and Lauterbach (2016) concluded, graduation rates are not well understood. 
The large American NLTS2 study showed that students with disabilities are more likely to attend 2-year or community colleges than 4-year colleges or universities (Newman et al., 2011). As well, it is important to note that approximately half of the students who self-report disabilities do not register to receive disability-related services from their schools (Fichten et al., 2016, 2018). These students must cope with their access needs, including their ICT-related access needs, on their own.

The North American and European economies have become progressively more knowledge based. This makes an HE credential more important (Carnevale \& Desrochers, 2003). Education helps individuals with disabilities obtain employment (Getzel \& Thoma, 2008; Shaw, Gold, \& Wolffe, 2007). For example, a recent study found that of those HE graduates with disabilities in the labor force (i.e., employed or looking for work), $70 \%$ were employed a year after graduation (Jorgensen et al., 2015), a figure somewhat lower than the employment rate of students without disabilities. The same is true in the United Kingdom (Advance HE, 2018). Canadian, American, and British data show that students who enroll in but do not complete an HE program are less likely to be employed, and receive a lower salary than a graduate (Advance HE, 2018; Jorgensen et al., 2015; Ma, Pender, \& Welch, 2016).

There are a number of reasons for the large numbers of students with disabilities graduating from $\mathrm{HE}$ including: the increased recognition of the abilities of students with disabilities; a redefinition of disability that recognizes that this group includes students other than those with mobility and sensory disabilities; a de-medicalization of disability in the HE context; and the increased presence of ICTs within HE.

\section{Higher Education ANd InFORMATION and Communication Technologies: Turn of the Century to Current Times}

To understand the role and prevailing use of ICTs in HE, it is important to put the current situation in context. To do this, in this section we cover the evolution of specialized assistive technology (AT), the use of ICTs in online and face-to-face instruction ${ }^{1}$ and the blending of assistive and general use ICTs. ${ }^{2}$ 


\section{Specialized Assistive Technology}

In the 2000s, the medical model lost ground. In this framework, the emphasis was on managing the student's disability and on providing accommodations, including assistive technology (AT), for each student based on diagnosis and needs (National Educational Association of Disabled Students, 2012). Since the 2000s, the social model of disability, where the focus is on making changes to the environment to ensure accessibility to as many people as possible (McGuire, 2011), has been gaining strength in Canadian, American and British HE institutions (Black, Weinberg, \& Brodwin, 2015; Fichten et al., 2016; Thornton \& Downs, 2010). This includes the adoption of universal design concepts, which involve responding to the diversity of users from the outset, from the realm of products and buildings (Connell et al., 1995; Vanderheiden, 1993 ) to ICTs and HE (Ableser \& Moore, 2018; McGuire, Scott, \& Shaw, 2003; Thomson, Fichten, Budd, Havel, \& Asuncion, 2015).

With regard to HE professionals, a key finding is that mainstream ICT specialists on campus know very little about the technological needs of students with disabilities (Fichten et al., 2009). Subsequent research shows that while many students' ICT-related access needs are being reasonably well met, there is a key exception-training on how to use needed AT (e.g., screen reading software) (Fichten et al., 2012). These days, most large $\mathrm{HE}$ institutions have an assistive technologist on staff (e.g., Access Technology Higher Education Network (ATHEN) https://athenpro. org/). These individuals help students with their AT and also train students on how to use these. The same is not necessarily true for small institutions.

In investigations carried out by the Adaptech Research Network ${ }^{3}$ stu- $^{-}$ dents noted the high cost of specialized assistive technologies (e.g., screen reading software, specialized multipurpose software for students with learning disabilities). Students also shared low-cost alternatives. This resulted in the compilation, starting in 1999, of a listing of free or inexpensive hardware and software alternatives that might be useful for students with diverse disabilities. ${ }^{4}$ This compilation continues to grow and showcases both the "built-in" features of PCs, Macs, Android, and iOS devices as well as providing descriptions of a variety of free and low-cost software, hardware, and apps that are evaluated by the Adaptech team. Most smartphones and tablets include powerful built-in accessibility features for people with different disabilities. Given the role of mobile 
technologies in current and future $\mathrm{HE}$, the accessibility, usability, and affordability of apps for mobile devices is an exciting development (Fichten, Havel, Jorgensen, King, \& Harvison, 2019).

\section{E-Learning and Classroom Use of ICTs}

Most North American instructors use some form of instructional ICT in their courses (Schmid et al., 2014). This includes technologies such as PowerPoint, podcasts, videos, polling software, simulations, blogs, digital textbooks, course management systems, lecture capture, and web conferencing (Fichten et al., 2018; Tarawneh, Tarawneh, \& Alzboun, 2011). The extensive deployment of Wi-Fi in most HE institutions, along with mobile computing, is helpful to students with disabilities. These are especially helpful when professors upload their teaching materials in accessible formats and allow students to access these on their own devices.

Professors often make online materials available on a course website, course management system, or online education platform which allows students to interact with learning materials outside of the classroom (Lombardi, Murray, \& Gerdes, 2011). In some cases, the course management system (CMS)/virtual learning environment (VLE) system is itself problematic. A recent report (Policy Connect, 2018) was produced to help United Kingdom HE institutions adapt when new digital accessibility regulations came into force. The report states that the HE sector, "has a long way to go in making VLEs accessible to all" (p. 12). Digital accessibility problems in HE are not new. Fichten et al. (2009) surveyed over 200 students with disabilities and over 100 staff from Canadian colleges and universities regarding e-learning problems and solutions. "Problems specified by at least $10 \%$ of students were, in rank order: inaccessibility of websites/course management systems, technical difficulties, poor use of e-learning by professors, difficulty connecting to websites/course management systems, and students' lack of knowledge of how to use e-learning" (p. 247). Of particular concern is that across all groups, the most common response to questions around solutions was "unresolved." This applied to problems such as "inaccessibility of websites/CMS," "poor use of e-learning by professors" and "students' lack of knowledge of how to use e-learning." Recommendations for ensuring accessibility of AT and e-learning are made by Kenney et al. (2016).

Although online content can be inaccessible (e.g., no captioning of videos, PDF files containing scanned images that cannot be read by screen 
reading software), it is material used "on-the-fly" inside the classroom that can pose the most serious access challenges. For example, if the professor uses a video clip in class, this may not be available to the student who requires video description or subtitles. Or if they use a simulation or digital polling in class, students may not be able to download the results onto their devices to make it accessible. As Berkowitz (2008) cautioned over a decade ago, just because it is digital does not mean that it is usable or accessible to all.

HE libraries have been increasingly moving toward digital journals and e-books that can be read online or downloaded and borrowed for a predetermined number of days. The accessibility of these e-books varies, however. This trend notwithstanding, unless or until paper-based publications disappear completely from library shelves, colleges and universities must continue seeking ways to address the need for timely access to print material. This was demonstrated by the 2013 settlement agreement involving America's UC Berkeley's library (Schwartz, 2013), which underscored that this need is still very much a reality. Fortunately, technology exists to convert most print material into electronic formats.

Active learning using digital whiteboards (e.g., Smart Boards), cooperative learning, and flipped classrooms have also become popular (Lasry, Dugdale, \& Charles, 2014). This can include interactive white boards (e.g., SMART board) and study pods where students all have digital access and teach each other. A challenge when it comes to interactive white boards is how to make both the content and the ability to use them, accessible to both students with visual or hearing impairments and to students with attention-deficit issues who have difficulty in noisy "team" environments and can get lost in the multiplicity of activities (Gonzalez, 2016). Nevertheless, efforts are ongoing to make active learning accessible (e.g., Illinois State University Media Relations, 2012; Summers \& Brauner, 2012).

Universal design is a mainstream concept championed by offices that provide disability-related supports on campus (Ableser \& Moore, 2018; Burgstahler, 2015; CAST, 2018). Universal design concepts are starting to emerge-although slowly - out of the disability arena (Davies, Schelly, \& Spooner, 2013). For example, text-to-speech software has excellent potential for proofreading papers for everyone (Greenbaum, 2014). Captioned videos could help all students with spelling of technical terms or unfamiliar names or words. The use of universal design in e-learning, however, is usually more by happenstance than intention (e.g., PowerPoint and course notes on websites are available to all, but can be considered an 
access accommodation for students with certain disabilities). Social media are also increasingly used in academia (Selwyn, 2012). How accessible these are to students with different disabilities varies, however (Asuncion et al., 2012). For example, effective YouTube captioning is still not as widely used as it can be.

The vast majority of students with and without a disability have a smartphone. For example, $97 \%$ of student participants in the large EDUCAUSE student survey by Brooks and Pomerantz (2017) reported owning a smartphone. In a smaller study that included two samples comprised of 46 $\mathrm{HE}$ students with and $46 \mathrm{HE}$ students without disabilities $100 \%$ of both groups owned a smartphone (Chmilar \& Anton, 2018). Smartphones have different levels of built-in features meant to provide access to people with disabilities. There is also the growing number of free or inexpensive software solutions available to support persons with disabilities. ${ }^{4}$ These developments, along with the trend toward universal design, hold promise for meeting the future technology and e-learning accessibility needs of students with diverse disabilities.

\section{Blurring the Lines Between Adaptive and General Use ICTs}

In a study that is now almost two decades old, close to $800 \mathrm{HE}$ students with disabilities were asked what computer and/or adaptive computer technologies they considered could be useful in getting their academic work done (Fichten et al., 2001). In rank order, the top ten for students with all types of disabilities combined was: spelling/grammar checker, scanner, portable note-taking device, dictation software, alternate format materials (e.g., books, hand-outs), specialized software for learning disabilities (e.g., word prediction), voice control software (voice commands like "file," "open"), a large screen monitor, text-to-speech software (reads what's on the screen), and mouse adaptations.

The results highlight that technology considered general use ICTs are, in fact, used as AT by students with certain disabilities. For example, the ubiquitous spell checker was used by students with learning disabilities as an AT. Dictation (speech-to-text/voice recognition) software, a key feature of Apple and Android devices, is used as an AT by students with a variety of hand/arm impairments and some types of learning disabilities. Text-to-speech screen reading technologies, originally used by people with visual impairments, have crossed over into the mainstream. The same is true for scanners and optical character recognition software, which are 
used as AT by students with visual and other print impairments. However, experts are not necessarily aware of the way students are using ICTs. For example, a study by Fichten et al. (2013) showed important gaps in a comparison of experts' ICT recommendations and ICTs actually used by HE students with learning disabilities. First, students with a learning disability did not report using many of the high-end software that experts believed could benefit them. Conversely, experts did not mention some software tools and apps that students did indicate using to do their school work, such as office suites, smartphones, MP3 players, instant messaging, and concept mapping.

Blurring of the division between assistive and general use technologies has allowed students with disabilities access to a vast array of technologies from which to choose. This includes: open source technologies, such as WordPress, Khan Academy, and MySQL; built-in features of software, such as effective dictation, magnification, and narration software built into general use technologies such as Office 365 and Android and iOS devices; general use hardware and software, including inexpensive printers with automatic sheet feeders and bundled scanning and optical character recognition (OCR) software; and inexpensive apps for smartphones and tablets that are useful and usable by students with and without disabilities.

\section{Higher Education and Information and Communication Technologies: The Next Wave}

New ICTs are expected to be integrated in HE institutions in the coming years. These have the potential to reengineer teaching and learning processes for students with disabilities (Jones, Williams, \& Rudinger, 2018), assuming, of course, that they are designed with accessibility in mind and the procurement of institution-wide technologies follows accessibility guidelines.

\section{Mobile Technologies}

Mobile technologies such as laptops, smartphones, and tablets are one of the most promising kind of ICTs (Alexander et al., 2019; Hershkovitz \& Forkosh-Baruch, 2017). Mobile technologies provide a rich range of learning tools, including applications, games, digital books with interactive elements, visual content, camera, and browsers, enabling mobile and flexible learning with no boundaries of space and time (Fichten et al., 2019). 
Mobile technologies enable learning any place and any time, while building new knowledge, creativity and cooperation in educational contexts (Hershkovitz \& Forkosh-Baruch, 2017). Mobile devices are a gateway to accessible learning environments, enabling the use of accessible content and the exploration of subjects at a personal pace. In this context, "wearable technologies" are often manufactured in the form of clothing accessories such as jewelry, sunglasses, backpacks, and shoes, enabling, among other features, studying and sending email. These advanced technologies can increase students' involvement and motivation to learn, help develop innovative learning skills and, above all, enable learning outside the classroom (Ferreira, Moreira, Pereira, \& Durão, 2015). Mobile technologies can also motivate students to learn and persevere in tasks, to personalize learning and to enable students to be active in the process of learning.

Mobile technologies can particularly assist students with disabilities. This is especially applicable in HE because most students own mobile devices and most academic institutions provide free access to wireless networks. This makes the use of mobile devices inexpensive, convenient, and easy. However, professors often dislike the presence of students' personal devices in class and, in some cases, forbid their presence (Fichten et al., 2019). Indeed, the Educause: Continuing to Look to the Horizon (2019) website rates "rethinking the practice of teaching" as a "wicked" problem and states that this is a difficulty that is "complex to even define, much less address." Whether the benefits of mobile computing and their actual effect on learning for students with disabilities are realized is a matter for empirical investigation.

\section{Cloud Computing}

Cloud technology has already started to assist all students, including those with disabilities. Cloud services enable students to access a variety of online resources, services, and tools that do not consume processing and memory resources on their devices. This includes Office 365 , which has a variety of powerful built-in accessibility features. The use of cloud technology also provides flexibility and savings in computing costs and facilitates the use of mobile technologies such as smartphones and tablets because these have limited storage and memory capability. Current uses of cloud computing include software tools and collaborative applications, and access to learning materials, virtual labs, virtual worlds, media, email, and 
more (Adams Becker et al., 2017). Cloud technology can enable HE institutions to reduce costs. It also has benefits in the implementation of distance learning programs, of special interest to many students with disabilities.

\section{The Internet of Things}

The Internet of Things is the next technological step in the development of smart objects. It is a network of physical objects ("things") that incorporate digital components, software and sensors that enable advanced communication between the objects and the ability to collect and exchange information. This technology, introduced at the beginning of the second decade of the twenty-first century, is expected to expand significantly in the coming years in HE institutions. As a result, it will be possible to develop smart learning environments that will enable students to receive information from existing objects in the learning environment (e.g., a school laboratory, a botanical garden, an archeological park). This new technology has great potential for students with disabilities by making learning systems much more accessible. But will this actually come to pass? Our review presented in the next section suggests that it will only come about if practices within $\mathrm{HE}$ change.

\section{Artificial Intelligence}

Artificial Intelligence (AI) has enormous implications for students with disabilities. The Educause: Continuing to Look to the Horizon (2019) website suggests that AI will be incorporated into $\mathrm{HE}$ within the next two years. For instance, in the future, professors may transform learning into an interactive experience through the use of personal artificial intelligence tutors, helping students with disabilities access lectures at their own pace with personalized AI help (Lynch, 2018). While the development of educational AI may have great promise in advancing full inclusion and effective study processes for students with disabilities, a variety of concerns have been noted. These include issues related to equity, inclusion and privacy (Alexander et al., 2019). We would like to add accessibility to the list of challenges. Indeed, few of the innovations we have outlined in this section on new wave ICTs will succeed in providing positive learning experiences for students with disabilities unless they are designed with 
their needs in mind. Designers must also avoid repeating the problematic practices that we highlight in the next section.

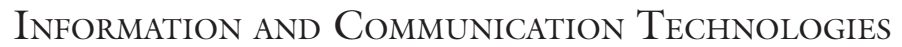 and Students with Disabilities: The Good, the Bad, and the Really Problematic Practices}

The cost of assistive software and hardware, the current generation of students' personal mobile technologies, as well as online and face-to-face teaching with digital technologies has resulted in both good and bad outcomes for students with disabilities. In this section, we offer a selection of examples to illuminate the many good, bad, and terrible examples of ICTrelated practices experienced by HE students.

\section{The Good}

In the United Kingdom, Disabled Students' Allowances (UCAS, 2018) are available to eligible students. The Allowance can fund both technological and human support. What makes this especially good is that data show that Allowance awards have a favorable impact on graduation; $73.9 \%$ of students with disabilities who qualified and received the Allowance achieved first-class or upper second-class honors compared to $72.5 \%$ of those who did not receive the Allowance (Advance HE, 2018). In addition, the Policy Connect (2018) report cites some examples of good practice in $\mathrm{HE}$, such as lecture recordings with transcripts (University of Southampton), an audit of e-book formats used to inform the procurement of content (University of Kent), and the use of the virtual learning environments to provide alternative assessment types (Bournemouth University).

Student views expressed at the series of Ed-ICT Symposia show that students have many powerful, readily available resources to teach themselves how to use ICTs if training from the HE institution is unavailable. These include Google and YouTube (M. Jorgensen, Fichten, King, \& Havel, 2018). Technology has also promoted online learning which allows students with certain disabilities, such as mobility impairments and mental illness, to participate fully in HE; students can access the course at home and still feel like they are part of the class (Heiman, Olenik-Shemesh, Kaspi-Tsahor, \& Regev-Nevo, 2018). For students who attend face-to- 
face classes, technology has facilitated note-taking, as students can record lectures using their smartphones (Heiman et al., 2018) and they can download professors' notes if these are uploaded before class (University of Washington, 2017). Studying has also been facilitated by technology as a result of subject-specific applications, such as MathType, apps such as Zoom that allow students to listen to the professor's lecture at home (Heiman et al., 2018), and concept mapping software, such as Inspiration, which help students structure their ideas (University of Washington, 2017).

\section{The Bad}

In America, publishers are struggling to provide accessible digital versions of textbooks. Accessibility is hampered by proprietary technologies that include publishers' own screen reading software that is not appropriate for all students. Older books are not always available in digital formats. Although the technical issues reported by Cooper (2014) have been resolved by developments in MathML and MathJax and by web browsers' support for these technologies, math related texts still pose a huge challenge (D. Comden, personal communication, December, 2018). Publishers of Canadian texts often provide no accessible formats at all. This is especially true of materials in French. Moreover, digital course packs are often inaccessible. For example, Canada's Concordia University Student Hub (n.d.) wrote on the university website in February, 2019, "The Bookstore sells digital versions of many of its course-packs, but cannot guarantee that they are universally accessible. The ACSD therefore recommends that students who'd like to have their course-packs converted purchase the hard copies."

HE websites are often not fully accessible. Seale (2014) analyzed the results of a range of studies that tested the accessibility of university home pages as well as program/course pages and library pages in a range of countries including the United States, Canada, and Europe. She concluded that there was still clear evidence of a lack of accessibility. More recently, Alahmadi and Drew (2017) evaluated a sample of 3 pages from the websites of 60 top-ranking universities in the world, including Oceania and the Arab states, using the Achecker (2011) tool. They found high numbers $(\sim 3000)$ of problems in each region, "Of the 82,685 errors on the 180 pages, there were 30,944 home page errors $(37.42 \%$ of the total), 24,433 admission page errors $(29.55 \%$ of the total) and 27,308 course description page errors (33.03\% of the total)" (p. 15). The authors con- 
sider this a global problem which shows that HE institutions pay minimal attention to accessibility. Alahmadi and Drew compared their findings to previous similar studies from 2005 to 2014 and found that although there has been a slight improvement, the situation remains problematic.

Other examples include reports by Canadian, American and Israeli students with disabilities who participated in the Ed-ICT Symposia. ${ }^{5}$ They reported that they do not have the time required to learn how to use specialized ICTs. Furthermore, students are not always aware of what technologies are available to help them succeed academically. There is also a lack of training about how to use AT, so students often do not know how to use the technology or they have to teach themselves (Heiman et al., 2018; Jorgensen et al., 2018; University of Washington, 2017). For example, one student said that they had to train themselves to use a screen reader and refreshable braille display (University of Washington, 2017). In addition, students complained about incompatibility of platforms and difficulties with general use technologies because the latest versions used by their HE institution were incompatible with their AT, which often lagged a version behind.

Students with disabilities can also become frustrated when the experts, who are supposed to show them how to use AT, do not understand their perspective. For example, at the Tel Aviv Ed-ICT symposium, a student who is blind reported that an expert was not prepared to show them how to use an application and software from the perspective of someone who cannot see the screen. Students also reported many errors made by textto-speech software. This is particularly problematic for students who are blind or have visual impairments because they may not be able to read the text itself to correct the mistake. One student who was blind said that they had to upgrade their JAWS program to correct for such errors, but it was very expensive (Heiman et al., 2018). In Israel, the problem is endemic (Kaspi-Tsahor, Heiman, \& Olenik-Shemesh, 2018).

\section{The Really Problematic}

Most Canadian HE libraries do not have accessible digital copies of textbooks because of copyright legislation; only the student with a disability is entitled to have digital copies of many texts. In case of disputes with their HE institution, students must take their case to the Canadian Human Rights Commission (Government of Canada, 2018), which can take several semesters to hear the case. Moreover, this group does not work 
with precedents - each case is unique. Other Canadian examples of inaccessibility and poor practice include the location of accessible computer labs in buildings far from the student's classes, professors who do not allow students with disabilities to use their personal mobile technologies in class, and government policies that do not allow students to use their AT for final exams. This latter issue is also common in Israel (Kaspi-Tsahor et al., 2018). In addition, in Israel, because of the small population and the nature of the alphabet, Google Translate and text to-speech apps work especially poorly (Kaspi-Tsahor et al., 2018).

Universities continue to procure technology that is not accessible (D. Comden, personal communication, December 2018), resulting in problems in the future. Procurement by HE institutions of accessible ICTs was raised as an issue at the Ed-ICT Symposia (2019). There appears to be very little research in the area of procurement of accessible ICTs for HE institutions, and there are conceptual issues related to accessibility that need to be included in the procurement process (cf. Cravero, 2017). As early as 2006 (Seale, 2006), Seale identified this as one of the key adjustments that institutions can make in response to disability-related legislation. However, we are not aware of any studies in which the complex reasons for accessibility not being fully considered within procurement processes in HE institutions are analyzed.

According to student testimonials at Ed-ICT Symposia (2019), in Canada there is a lack of adequate government funding for students to access ICTs. This is problematic given the ubiquitous use of mobile applications in $\mathrm{HE}$, which $\mathrm{HE}$ services cannot provide or lend to students (Jorgensen et al., 2018). Another barrier to students accessing ICTs is the high costs of some ICTs (Heiman et al., 2018; Jorgensen et al., 2018). In addition, students with disabilities have difficulty using computers with needed AT at their institution due to restricted lab hours. Lab hours can also be problematic for some students because they cannot stay late at the college because of adapted transportation schedules.

Students at the Ed-ICT Symposia (2019) related that there were compatibility problems between MAC and Windows computers. This can be especially problematic for students with disabilities who have restricted access to computer labs at the HE institution and who have to rely on using their own personal computer, which may have their needed AT but fail to work with the school's software. Some of the barriers that students must overcome in accessing ICTs also arise when the HE institution 
upgrades software or makes changes to learning platforms and websites, such as online course websites (Heiman et al., 2018). When the upgrades and updates are done, new online course websites may not be accessible to students because the updates are not compatible with older versions of AT that the students are using.

\section{Implications for Future Research and Practice}

Given the difficulties we have outlined concerning access to and use of ICT by students with disabilities in HE, we suggest that there are many things that could help to remove barriers: the push to incorporate universal design into learning; the move away from the medical toward the social model of disability; technology innovation in general; advances in adaptive hardware and software; the presence of free and low-cost technologies deemed useful by people with disabilities; increasing awareness of digital accessibility; adoption of institutional digital accessibility policies; disability-specific legislation that addresses digital inclusion; as well as changes in the way learning is being delivered using all forms of ICTs. We do however wish to highlight two issues that we feel are particularly important and that have implications for both research and practice: (1) stakeholder knowledge of ICT and (2) design and development issues.

\section{Stakebolder Knowledge of ICT}

Despite the central importance innovative developments such as Artificial Intelligence, the Internet of Things and those that will come in the future and the issues identified earlier in this chapter there remain a variety of difficulties related to their integration for assisting students with disabilities in HE. One significant issue is that ICT specialists, procurement officers, librarians, faculty, and other stakeholders know very little about the technological needs of students with disabilities. There is a need to develop education modules concerning how to meet the ICT-related needs of students with different disabilities for these professionals. Assistive technologists can help to promote an in-depth understanding of the AT that students with different disabilities use and how this is related to general use learning and educational technologies. 


\section{Design and Development Issues}

Another future change in practice that arises from the research and from the experiences of students with disabilities is the inclusion of students with disabilities in the early stages of the development of new innovative technologies. The expertise of students about the needs of students with disabilities appears to be necessary during the process of development to ensure not only accessibility but also usability.

The challenges of HE budget and priorities are also always there. New ATs require expensive financing in their development. This is passed on to the limited numbers of students who require these for individual use (Treviranus, 2019). A key challenge is how to develop AT that will enable students with disabilities to use them, regardless of their economic ability. In addition, research is needed concerning $\mathrm{HE}$ policies regarding the integration, deployment, and budgeting for new AT for students with disabilities. Very little research has been done on these issues thus far.

A well-developed progressive society provides students with disabilities with a great deal of autonomy to manage their lives and solve problems. It encourages them to acquire $\mathrm{HE}$ as a tool to increase their inclusion in society and obtain employment (Feldman, Danieli, Lahav, \& Haimovich, 2007). We would argue that this principle should be a guiding light for ICT developers and administrators in the HE systems.

\section{Conclusion}

In 2020, few will argue that without some level of digital skill or knowhow, all HE graduates, including those with disabilities, will be at a significant disadvantage when entering the labor market. This is why in HE institutions, from applying to schools to selecting and then taking courses, and almost every other aspect of the curricular and extra-curricular experience has a technology basis. Given the number of students with disabilities in $\mathrm{HE}$, the imperative is that all of the digital experiences across the curriculum and the campus must be accessible and inclusive. Failure to do so puts these students at a disadvantage relative to their nondisabled peers, especially when seeking employment.

Students with disabilities, however, continue to face a variety of barriers, including inaccessible digital course materials and websites; lack of training on how to use needed AT, poor compatibility between software used by the HE institution and students' AT; libraries that do not stock 
accessible digital textbooks or course packs; professors who do not allow students with disabilities to use their personal mobile technologies in class; procurement of inaccessible HE technologies that will affect teaching and learning for many years; the high cost of some AT; and restricted access to computer labs. Moreover, many HE institutions simply pay minimal attention to accessibility. To overcome these barriers, enhancing the knowledge of ICT stakeholders, including students with disabilities, in the design and development of new technologies and examining HE policies are key priorities for researchers and practitioners in the field.

\section{Notes}

1. This section is based on Fichten, C. S., Asuncion, J., \& Scapin, R. (2014). Digital technology, learning, and postsecondary students with disabilities: Where we've been and where we're going. Journal of Postsecondary Education and Disability, 27(4), 369-379.

2. This section is based on Fichten, C. S., Nguyen, M. N., King, L., Barile, M., Havel, A., Mimouni, Z., Chauvin, A., Budd, J., Raymond, O., Juhel, J.-C., \& Asuncion, J. (2013). Information and communication technology profiles of college students with learning disabilities and adequate and very poor readers. Journal of Education and Learning, 2(1), 176-188.

3. http://www.adaptech.org

4. http://www.adaptech.org/en/downloads

5. Ed-ICT International Network Symposia. http://ed-ict.com/workshops/

\section{REFERENCES}

Ableser, J., \& Moore, C. (2018, September 10). Universal Design for Learning and digital accessibility: Compatible partners or a conflicted marriage? Educause Review. Resource document. EDUCAUSE. https://er.educause.edu/articles/2018/9/ universal-design-for-learning-and-digital-accessibility-compatiblepartners-or-aconflicted-marriage\#fnr2

Achecker. (2011). Web accessibility checker. https://achecker.ca/checker/index. php. Accessed 26 Sep 2019.

Adams Becker, S., Cummins, M., Davis, A., Freeman, A., Hall Giesinger, C., \& Ananthanarayanan, V. (2017). NMC Horizon Report: 2017 higher education edition. Resource document. The New Media Consortium. http://cdn.nmc. org/media/2017-nmc-horizon-report-he-EN.pdf

Advance HE. (2018, September). Equality and higher education: Students statistical report 2018. Resource document. Advance HE. https://www.ecu.ac.uk/ publications/equality-higher-education-statistical-report-2018/ 
Alahmadi, T., \& Drew, S. (2017). Accessibility evaluation of top-ranking university websites in world, Oceania, and Arab categories for home, admission, and course description webpages. Journal of Open, Flexible and Distance Learning, $21(1), 7-24$.

Alexander, B., Ashford-Rowe, K., Barajas-Murphy, N., Dobbin, G., Knott, J., McCormack, M., et al. (2019). EDUCAUSE Horizon Report: 2019 higher education edition. Resource document. EDUCAUSE. https://library.educause. edu/-/media/files/library/2019/4/2019horizonreport.pdf?la=en\&hash=C 8E8D444AF372E705FA1BF9D4FF0DD4CC6F0FDDI

Arim, R. (2017, February 15). A profile of persons with disabilities among Canadians aged 15 years or older, 2012. Resource document. Statistics Canada, Catalogue No. 89-654-X. http://www.statcan.gc.ca/pub/89-654-x/89-654x2015001-eng.pdf

Asuncion, J. V., Budd, J., Fichten, C. S., Nguyen, M. N., Barile, M., \& Amsel, R. (2012). Social media use by students with disabilities. Academic Exchange Quarterly, 16(1), 30-35.

Berkowitz, D. (2008, March). Digital does not equal accessible. Presentation for NERCOMP (EDUCAUSE), Providence, Rhode Island.

Black, R. D., Weinberg, L. A., \& Brodwin, M. G. (2015). Universal design for learning and instruction: Perspectives of students with disabilities in higher education. Exceptionality Education International, 25(2), 1-16.

Brooks, D. C., \& Pomerantz, J. (2017, October). ECAR study of undergraduate students and information technology, 2017. Resource document. EDUCAUSE Center for Analysis and Research. https://library.educause.edu/ /media/ files/library/2017/10/studentitstudy2017.pdf

Burgstahler, S. (2015). Universal design of instruction: From principles to practice. In S. E. Burgstahler (Ed.), Universal design in higher education: From principles to practice (2nd ed., pp. 31-64). Boston: Harvard Education Press.

Carnevale, A. P., \& Desrochers, D. M. (2003). Preparing students for the knowledge economy: What school counselors need to know [special issue]. Professional School Counseling, 6(4), 228-236.

CAST. (2018). Universal Design for Learning guidelines version 2.2. Resource document. CAST. http://udlguidelines.cast.org

Chmilar, L., \& Anton, C. (2018). Mobile learning: Device ownership, usage, and perspectives of post-secondary students with and without disabilities. The Journal on Technology and Persons with Disabilities, 6, 117-126.

Concordia University Student Hub. (n.d.). Request course packs in alternate formats. Resource document. Concordia University. https://www.concordia.ca/ students/accessibility/e-text-service/requesting-course-packs-in-alternateformats.html

Connell, B. R., Jones, M., Mace, R., Mueller, J., Mullick, A., Ostroff, E., et al. (1995, December 7). The principles of universal design. Version 1.1. Resource 
document. TRACE. http://web.archive.org/web/19991008040849/ http://trace.wisc.edu/text/univdesn/ud_princ/ud_princ.html

Cooper, M. (2014). Meeting the needs of disabled students in online distance education - An institutional case study from the Open University, UK. Distance Education in China, 2014(12), 18-27.

Cravero, C. (2017). Socially responsible public procurement and set-asides: A comparative analysis of the US, Canada and the EU. Arctic Review on Law and Politics, 8, 174-192. https://doi.org/10.23865/arctic.v8.739.

DaDeppo, L. M. (2009). Integration factors related to the academic success and intent to persist of college students with learning disabilities. Learning Disabilities Research \& Practice, 24(3), 122-131. https://doi.org/ 10.1111/j.1540-5826.2009.00286.x.

Davies, P. L., Schelly, C. L., \& Spooner, C. L. (2013). Measuring the effectiveness of universal design for learning intervention in postsecondary education. Journal of Postsecondary Education and Disability, 26(3), 195-220.

Eagan, M. K., Stolzenberg, E. B., Zimmerman, H. B., Aragon, M. C., Whang Sayson, H., \& Rios-Aguilar, C. (2017). The American freshman: National norms fall 2016. Los Angeles: Resource document. Higher Education Research Institute, UCLA. https://www.heri.ucla.edu/monographs/ TheAmericanFreshman2016.pdf

EDUCAUSE. (2019). Continuing to look to the horizon. Resource document. EDUCAUSE. https://library.educause.edu/resources/2019/4/2019horizon-report

Feldman, D., Danieli, L., Lahav, Y., \& Haimovich, S. (2007). Accessibility of the society in Israel at the beginning of the 21st century. The organization for Equality for People with Disabilities, Israeli Ministry of Justice.

Ferreira, M. J., Moreira, F., Pereira, C. S., \& Durão, N. (2015). The role of mobile technologies in the teaching/learning process improvement in Portugal. Proceedings of the 8th Annual International Conference of Education, Research and Innovation, Spain, 4600-4610. https://www.researchgate.net/publication/287644975_THE_ROLE_OF_MOBILE_TECHNOLOGIES_IN_ THE_TEACHINGLEARNING_PROCESS_IMPROVEMENT_IN_ PORTUGAL, http://repositorio.uportu.pt/jspui/bitstream/11328/1352/1/ ICERI_2015_2150_vFinal.pdf. Accessed 26 Sep 2019.

Fichten, C., Havel, A., Jorgensen, M., King, L., \& Harvison, M. (2019). If you can't beat them, join them: using students' personal mobile devices in class. Academic Matters. Resource document. Dawson College. https://www.dawsoncollege.qc.ca/academic-matters/issues/2019-02/

Fichten, C., Jorgensen, M., Havel, A., King, L., Lussier, A., Asuncion, J., et al. (2018). Information and communication technologies: Views of Canadian college students and "excellent" professors. Journal of Education and Training Studies, 6(9), 1-12. https://doi.org/10.11114/jets.v6i9.3390. 
Fichten, C. S., Asuncion, J., Barile, M., Généreux, C., Fossey, M., Judd, D., et al. (2001). Technology integration for students with disabilities: Empirically based recommendations for faculty. Educational Research and Evaluation: An International Journal on Theory and Practice, 7(2-3), 185-221. https://doi. org/10.1076/edre.7.2.185.3869.

Fichten, C. S., Asuncion, J., \& Scapin, R. (2014). Digital technology, learning, and postsecondary students with disabilities: Where we've been and where we're going. Journal of Postsecondary Education and Disability, 27(4), 369-379.

Fichten, C. S., Asuncion, J. V., Wolforth, J., Barile, M., Budd, J., Martiniello, N., \& Amsel, R. (2012). Information and communication technology related needs of college and university students with disabilities. Research in Learning Technology, 20, 323-344. https://doi.org/10.3402/rlt.v20i0.18646.

Fichten, C. S., Ferraro, V., Asuncion, J. V., Chwojka, C., Barile, M., Nguyen, M. N., et al. (2009). Disabilities and e-learning problems and solutions: An exploratory study. Educational Technology \& Society, 12(4), 241-256.

Fichten, C. S., Havel, A., King, L., Jorgensen, M., Budd, J., Asuncion, J., et al. (2018). Are you in or out? Canadian students who register for disability-related services in junior/community colleges versus those who do not. Journal of Education and Human Development, 7(1), 166-175. https://doi. org/10.15640/jehd.v7nlal9.

Fichten, C. S., Heiman, T., Havel, A., Jorgensen, M., Budd, J., \& King, L. (2016). Sustainability of disability-related services in Canada - Israel: Will the real universal design please stand up? Exceptionality Education International, 26(1), 19-35.

Fichten, C. S., Nguyen, M. N., King, L., Barile, M., Havel, A., Mimouni, Z., et al. (2013). Information and communication technology profiles of college students with learning disabilities and adequate and very poor readers. Journal of Education and Learning, 2(1), 176-188. doi:https://doi.org/10.5539/ jel.v2nlp176.

Getzel, E. E., \& Thoma, C. A. (2008). Experiences of college students with disabilities and the importance of self-determination in higher education settings. Career Development and Transition for Exceptional Individuals, 31(2), 77-84. https://doi.org/10.1177/0885728808317658.

Gonzalez, F. (2016, December). For some, active learning can be a nightmare. Resource document. ASEE PRISM. http://www.asee-prism.org/last-worddec-4/

Government of Canada. (2018, October 22). Canadian Human Rights Commission. Resource document. Government of Canada. https://www.canada.ca/en/human-rights-commission.html

Greenbaum, D. (2014, September). Use text-to speech functions for better proofreading. Resource document. Lifehacker. http://lifehacker.com/use-text-tospeech-functions-for-betterproofreading-1629329673 
Heiman, T., Olenik-Shemesh, D., Kaspi-Tsahor, D., \& Regev-Nevo, M. (2018). Proceedings of the Ed-ICT International Network Israel Symposium: In Search of New Designs. The Open University of Israel. Resource Document. Ed-ICT. http://ed-ict.com/wp-content/uploads/2018/09/ProceedingsEdICTIsraelSymposium.pdf

Herbert, J. T., Hong, B. S. S., Byun, S.-Y., Welsh, W., Kurz, C. A., \& Atkinson, H. A. (2014). Persistence and graduation of college students seeking disability support services. Journal of Rehabilitation, 80(1), 22-32.

Hershkovitz, A., \& Forkosh-Baruch, A. (2017). Integrating mobile technology in higher education instruction [translation]. Academic Teaching, 6, 21-29.

Illinois State University Media Relations. (2012, July 3). SMART Boards for visually impaired. Report: The Illinois State University Faculty-Staff Newsletter. Resource document. The Illinois State University. http://mediarelations.illinoisstate.edu/report/1213/july3/smartboards.asp

Jones, B., Williams, N., \& Rudinger, B. (2018). Designing and implementing an assistive technology lab for post-secondary education. Education Sciences, 8(1). https://doi.org/10.3390/educsci8010011.

Jorgensen, M., Fichten, C., King, L., \& Havel, A. (2018). Proceedings of the Ed-ICT International Network Montreal Symposium: Stakeholder Perspectives. Resource document. Montréal, Québec: Adaptech Research Network. https:// eric.ed.gov/?id=ED580147

Jorgensen, M., Fichten, C. S., Nguyen, M. N., Budd, J., Barile, M., Asuncion, J., et al. (2015). Employment realities of recent junior/community college and university graduates and premature leavers with disabilities. International Journal of Disability, Community, and Rebabilitation, 14(1). Resource document. IJDCR. http://www.ijdcr.ca/VOL14_01/articles/jorgenson.shtml

Jorgensen, S., Fichten, C. S., Havel, A., Lamb, D., James, C., \& Barile, M. (2003). Students with and without disabilities at Dawson College graduate at the same rate. The Journal for Vocational Special Needs Education, 25(2-3), 44-46.

Jorgensen, S., Fichten, C. S., Havel, A., Lamb, D., James, C., \& Barile, M. (2005). Academic performance of college students with and without disabilities: An archival study. Canadian Journal of Counselling, 39(2), 101-117.

Kaspi-Tsahor, D., Heiman, T., \& Olenik-Shemesh, D. (2018, October). Support the transition of people with disabilities to post-compulsory education (PCE) and from PCE to employment. Paper presented at the 4th Ed-ICT International Network Symposium, Hagen, Germany. http://ed-ict.com/workshops/ hagen/programme/. Accessed 26 Sep 2019.

Kenney, M. J., Jain, N. R., Meeks, L. M., Laird-Metke, E., Hori, J., \& McGough, J. D. (2016). Learning in the digital age: Assistive technology and electronic access. In L. M. Meeks \& N. R. Jain (Eds.), The guide to assisting students with disabilities: Equal access in health science and professional education (pp. 119140). New York: Springer Publishing Company, LLC. 
Kimball, E. W., Wells, R. S., Ostiguy, B. J., Manly, C. A., \& Lauterbach, A. A. (2016). Students with disabilities in higher education: A review of the literature and an agenda for future research. In M. B. Paulsen (Ed.), Higher education: Handbook of theory and research (Vol. 31, pp. 91-156). Cham, Switzerland: Springer.

Knight, W., Wessel, R. D., \& Markle, L. (2018). Persistence to graduation for students with disabilities: Implications for performance-based outcomes. Journal of College Student Retention: Research, Theory \& Practice, 19(4), 362380. https://doi.org/10.1177/1521025116632534.

Lasry, N., Dugdale, M., \& Charles, E. (2014). Just in time to flip your classroom. The Physics Teacher, 52(1), 34-37. https://doi.org/10.1119/1.4849151.

Lombardi, A. R., Murray, C., \& Gerdes, H. (2011). College faculty and inclusive instruction: Self-reported attitudes and actions pertaining to universal design. Journal of Diversity in Higher Education, 4(4), 250-261.

Lynch, M. (2018, June). My vision for the future of the assistive technology in education. Resource document. The Edvocate. https://www.theedadvocate.org/ vision-future-assistive-technology-education/

Ma, J., Pender, M., \& Welch, M. (2016). Education pays 2016: The benefits of higher education for individuals and society. Resource document. The College Board. https://trends.collegeboard.org/sites/default/files/education-pays2016-full-report.pdf

McGuire, J. M. (2011). Inclusive college teaching: Universal design for instruction and diverse learners. Journal of Accessibility and Design for All, 1(1), 38-54. https://doi.org/10.17411/jacces.vlil.80.

McGuire, J. M., Scott, S. S., \& Shaw, S. F. (2003). Universal design for instruction: The paradigm, its principles, and products for enhancing instructional access. Journal of Postsecondary Education and Disability, 17(1), 10-20.

Ministry of Training, Colleges and Universities (Ontario). (2012). Update on students with disabilities. Postsecondary Education Division of Ontario. Presentation at the University of Michigan.

National Educational Association of Disabled Students (NEADS). (2012). Enhancing accessibility in higher education institutions: A guide for disability service providers. Resource document. NEADS. www.neads.ca/en/norc/eag/ eag_en.pdf

Newman, L., Wagner, M., Cameto, R., \& Knokey, A. (2009). The post-high school outcomes of youth with disabilities up to 4 years after high school: A report from the National Longitudinal Transition Study-2 (NLTS2) (NCSE 2009-3017). Resource document. National Center for Special Education Research, U.S. Department of Education. http://www.nlts2.org/reports/2009_04/ nlts2_report_2009_04_complete.pdf

Newman, L., Wagner, M., Knokey, A.-M., Marder, C., Nagle, K., Shaver, D., \& Wei, X. (2011). The post-high school outcomes of young adults with disabilities 
up to 8 years after high school: A report from the National Longitudinal Transition Study-2 (NLTS2). Resource document. National Center for Special Education Research. http://www.nlts2.org/reports/2011_09_02/ nlts2_report_2011_09_02_complete.pdf

Policy Connect. (2018, September). Accessible virtual learning environments: Making the most of the new regulations. Resource document. Policy Connect. https://www.policyconnect.org.uk/sites/site_pc/files/report/1134/fieldreportdownload/appgatreport09-18final.pdf

Rosenbaum, J. E. (2018). Disabilities and degrees: Identifying health impairments that predict lower chances of college enrollment and graduation in a nationally representative sample. Community College Review, 46(2), 145-175. https:// doi.org/10.1177/0091552118762630.

Schmid, R. F., Bernard, R. M., Borokhovski, E., Tamim, R. M., Abrami, P. C., Surkes, M. A., et al. (2014). The effects of technology use in postsecondary education: A meta-analysis of classroom applications. Computers \& Education, 72, 271-291. https://doi.org/10.1016/j.compedu.2013.11.002.

Schwartz, M. (2013, May 16). Settlement expands UC Berkeley library service to disabled. Library Journal. https://www.libraryjournal.com/? detailStory=settlement-expands-uc-berkeley-library-service-to-disabled. Accessed 26 Sep 2019.

Seale, J. (2006). E-learning and disability in higher education: Accessibility research and practice. Abingdon, UK: Routledge.

Seale, J. K. (2014). E-learning and disability in higher education: Accessibility research and practice (2nd ed.). Abingdon, UK: Routledge.

Selwyn, N. (2012). Social media in higher education. In A. Gladman (Ed.), The Europa world of learning (62nd ed., pp. 3-7). London: Routledge.

Shaw, A., Gold, D., \& Wolffe, K. (2007). Employment-related experiences of youths who are visually impaired: How are these youths faring? Journal of Visual Impairment of Blindness, 101(1), 7-21.

Snyder, T. D., de Brey, C., \& Dillow, S. A. (2016). Digest of education statistics 2015 (51st Ed.) (NCES 2016-014). Resource document. National Center for Education Statistics, U.S. Department of Education. https://files.eric.ed.gov/ fulltext/ED570993.pdf

Summers, E., \& Brauner, D. (2012, November 6). Viewing the smart board on an iPad. http://support.sas.com/misc/accessibility/education/ios/smartboard. html. Accessed 26 Sep 2019.

Tarawneh, H., Tarawneh, M., \& Alzboun, F. (2011). Enhancing the quality of e-learning systems via multimedia learning tools. International Journal of Computer Science Issues, 8(6), 107-111.

Thomson, R., Fichten, C., Budd, J., Havel, A., \& Asuncion, J. (2015). Blending universal design, e-learning, and information and communication technolo- 
gies. In S. E. Burgstahler (Ed.), Universal design in higher education: From principles to practice (2nd ed., pp. 275-284). Boston: Harvard Education Press. Thornton, M., \& Downs, S. (2010). Walking the walk: Modeling social model and universal design in the disabilities office. Journal of Postsecondary Education and Disability, 23(1), 72-78.

Treviranus, J. (2019). Learning to learn differently in higher education. Paper presented at the accesXchange Conference, Montréal, Québec.

UCAS. (2018). Disabled students'allowances. Resource document. UCAS. https:// www.ucas.com/student-finance-england/disabled-students-allowances

University of Washington. (2017). Symposium one: Effective models, frameworks, and approaches. Proceedings from the Ed-ICT International Network: Disabled students, ICT, post-compulsory education \& employment: In search of new solutions. Resource document. University of Washington, Seattle, WA. http:// ed-ict.com/wp-content/uploads/2017/06/Symposium-Effective_models_ frameworks_and_approaches_0.pdf

Vanderheiden, G. C. (1993). Accessible design: A handbook for more universal product design. Madison, WI: Trace Research and Development Center.

Wessel, R. D., Jones, J. A., Markle, L., \& Westfall, C. (2009). Retention and graduation of students with disabilities: Facilitating student success. Journal of Postsecondary Education and Disability, 21(3), 116-125. 